In cooperation with the Louisiana Department of Transportation and Development

\title{
Water Resources of Rapides Parish
}

\section{Introduction}

Rapides Parish, located in central Louisiana (fig. 1), contains fresh groundwater and surface-water resources. In 2005, about 443 million gallons per day (Mgal/d) were withdrawn from water sources in Rapides Parish (fig. 2). About 92 percent (409 Mgal/d) was withdrawn from surface water, and 8 percent ( $34 \mathrm{Mgal} / \mathrm{d}$ ) was withdrawn from groundwater (table 1). Withdrawals for power generation accounted for 91 percent $(403 \mathrm{Mgal} / \mathrm{d})$ of the total water withdrawn (table 2). Withdrawals for other uses included public supply (27 Mgal/d), irrigation ( 9 $\mathrm{Mgal} / \mathrm{d}$ ), and aquaculture (3 Mgal/d). Water withdrawals in the parish generally increased from 1960 to 1995 and decreased from 1995 to 2005 (fig. 2).

This fact sheet summarizes basic information on the water resources of Rapides Parish, La. Information on groundwater and surface-water availability, quality, development, use, and trends is based on previously published reports listed in the references section.
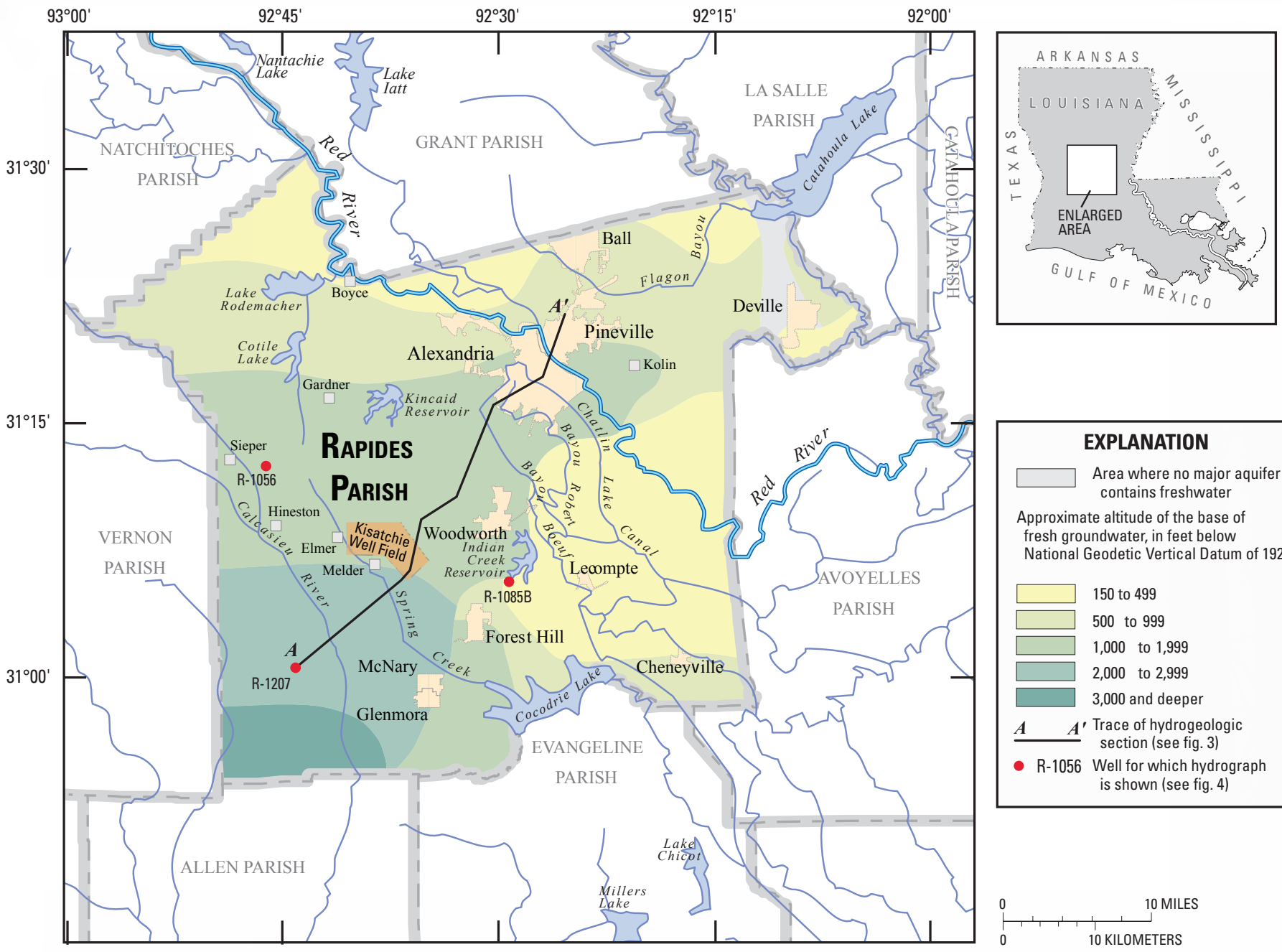

Base modified from Official Map of Louisiana, Louisiana Department of Transportation and Development, 1986

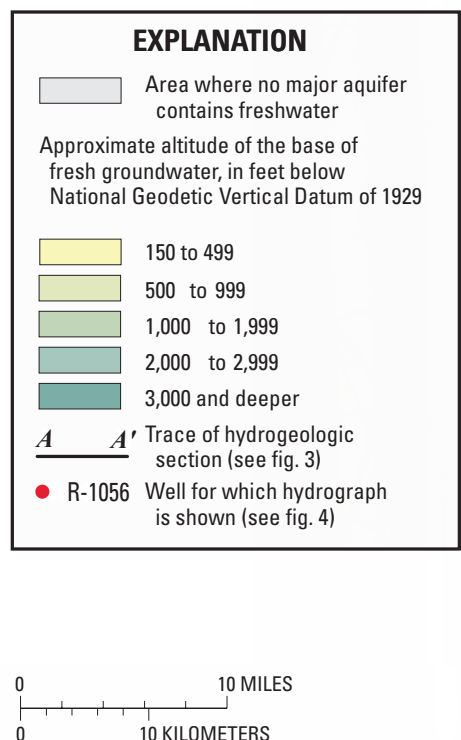

Figure 1. Location of study area, Rapides Parish, Louisiana. 


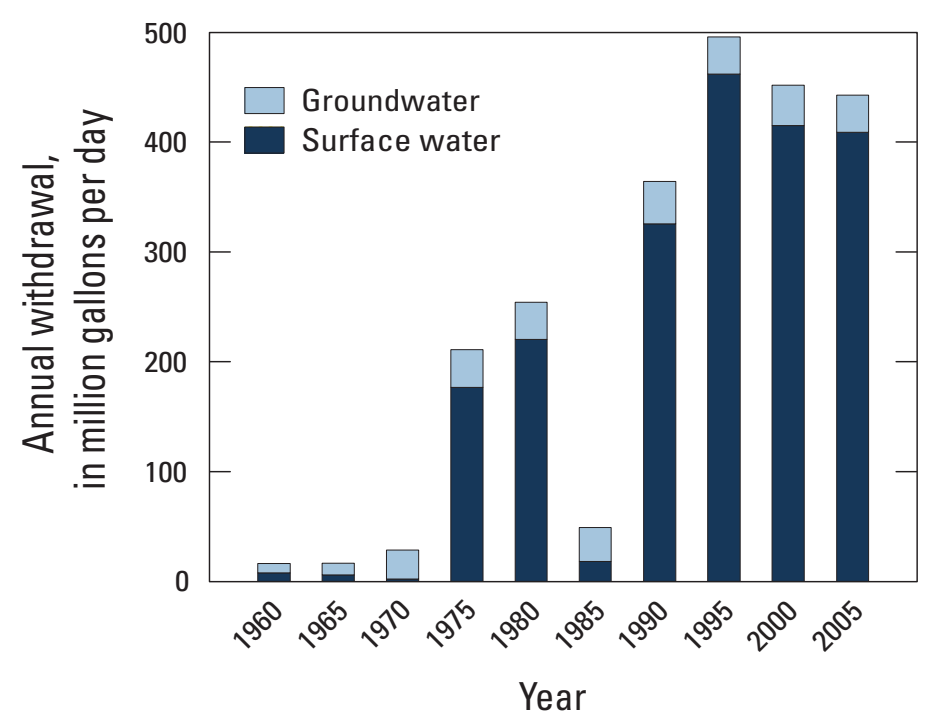

Figure 2. Water withdrawals in Rapides Parish, Louisiana, 1960-2005.

Table 1. Water withdrawals, in million gallons per day, by source in Rapides Parish, Louisiana, 2005 (Sargent, 2007).

\begin{tabular}{lcc}
\hline $\begin{array}{c}\text { Aquifer, aquifer system, } \\
\text { or major water body }\end{array}$ & Groundwater & Surface water \\
\hline Red River alluvial aquifer & 1.38 & \\
Upland terrace aquifer & 9.02 & \\
Chicot aquifer system & .76 & \\
Evangeline aquifer & 3.05 & \\
Jasper aquifer system & 18.5 & \\
Other aquifers & .91 & .95 \\
Bayou Boeuf & & 1.9 \\
Bayou Robert & & 402.39 \\
Chatlin Lake Canal & & .91 \\
Lake Rodemacher & & 409.09 \\
Other water bodies & & \\
Total & 33.63 & \\
\hline
\end{tabular}

Table 2. Water withdrawals, in million gallons per day, by category in Rapides Parish, Louisiana, 2005 (Sargent, 2007).

\begin{tabular}{lccc}
\hline & Groundwater & Surface water & Total \\
\hline Public supply & 27.17 & 0 & 27.17 \\
Industrial & .65 & 0 & .65 \\
Power generation & .12 & 402.39 & 402.51 \\
Rural domestic & .5 & 0 & .5 \\
Livestock & .03 & .12 & .15 \\
Rice irrigation & 3.03 & 4.54 & 7.57 \\
General irrigation & .69 & .69 & 1.39 \\
Aquaculture & 1.44 & 1.35 & 2.79 \\
\cline { 2 - 4 } Total & 33.63 & 409.09 & 442.72 \\
\hline
\end{tabular}

\section{Groundwater Resources}

The groundwater resources of Rapides Parish, from near surface to deepest, include the Red River alluvial and upland terrace aquifers; the Chicot aquifer system; and the Evangeline, Williamson Creek, and Carnahan Bayou aquifers (fig. 3). Fresh groundwater (water with a chloride concentration less than 250 milligrams per liter $[\mathrm{mg} / \mathrm{L}])$ is present from land surface to about $500 \mathrm{ft}$ below National Geodetic Vertical Datum of 1929 (NGVD 29) in northern and southeastern Rapides Parish (fig. 1) and to about 3,000 ft below NGVD 29 in the southwestern part of the parish. Recharge to the aquifers is from rainfall, leakage from overlying aquifers, and seasonal input from rivers. Discharge from the aquifers is by natural flow into rivers, leakage into underlying aquifers, and withdrawal from wells. Well-registration records from the Louisiana Department of Transportation and Development (DOTD) indicate that there are about 1,310 active wells screened in the aquifers in Rapides Parish, including about 770 domestic, 300 irrigation, 190 public-supply, and 40 industrial wells.

In 2005, about $27 \mathrm{Mgal} / \mathrm{d}$ of groundwater were withdrawn in Rapides Parish for public supply. The Alexandria Water System withdrew about $18 \mathrm{Mgal} / \mathrm{d}$ from well fields in the Kisatchie National Forest and in Alexandria. Water was also withdrawn for rice irrigation (3 $\mathrm{Mgal} / \mathrm{d}$ ) and aquaculture (1 Mgal/d).

\section{Shallow Aquifers}

For the purpose of this fact sheet, the Red River alluvial aquifer, upland terrace aquifer, and the Chicot aquifer system are grouped as shallow aquifers. These aquifers generally consist of fine to coarse sand and are present at depths shallower than $200 \mathrm{ft}$ below NGVD 29. About 610 wells are screened in the shallow aquifers, and most are used for domestic (336), irrigation (225), publicsupply (41), or industrial (12) purposes.

The Red River alluvial aquifer is 20 to $80 \mathrm{ft}$ thick and is present in about 30 percent of the parish in a band that extends from north-central to southeastern Rapides Parish. The aquifer yields very hard water (greater than $180 \mathrm{mg} / \mathrm{L}$ as calcium carbonate $\left[\mathrm{CaCO}_{3}\right]$ ), and iron and manganese concentrations generally exceed the U.S. Environmental Protection Agency's (EPA) 2006 Secondary Maximum Contaminant Levels (SMCLs) ${ }^{1}$ for drinking water. Chloride concentrations generally are less than $180 \mathrm{mg} / \mathrm{L}$; however, local areas contain saltwater (water with a chloride concentration that exceeds $250 \mathrm{mg} / \mathrm{L}$ ). Reported well yields are generally about 70 gallons per minute ( $\mathrm{gal} / \mathrm{min}$ ) but may be as much as $2,500 \mathrm{gal} / \mathrm{min}$ where the aquifer is

\footnotetext{
${ }^{1}$ The SMCLs are nonenforceable Federal guidelines regarding cosmetic effects (such as tooth or skin discoloration) or aesthetic effects (such as taste, odor, or color) of drinking water. At high concentrations or values, health implications as well as aesthetic degradation might exist. SMCLs were established as guidelines for the States by the U.S. Environmental Protection Agency (1992).
} 


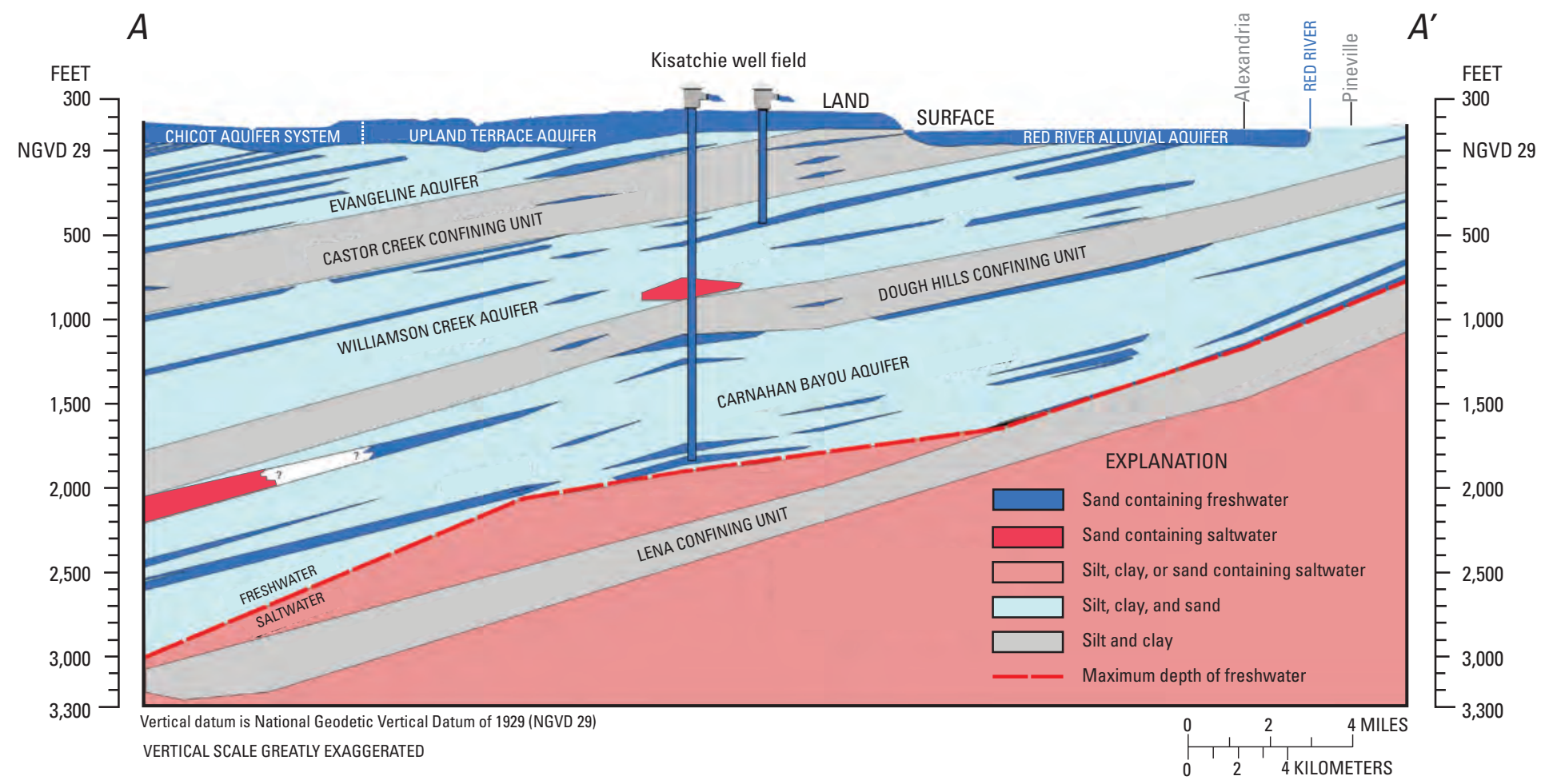

Figure 3. Generalized southwest-to-northeast hydrogeologic section through Rapides Parish, Louisiana (Tomaszewski, 2007). Trace of section shown on figure 1 .

thicker. Withdrawals from the Red River alluvial aquifer were about $1 \mathrm{Mgal} / \mathrm{d}$ in 2005. Water levels are about 50 to $70 \mathrm{ft}$ above NGVD 29. A comparison of water-level data from 1972 with data from 2000 indicates that water levels have changed little during the period.

The upland terrace aquifer and Chicot aquifer system are merged and indistinguishable in Rapides Parish. The aquifer and aquifer system are 70 to $160 \mathrm{ft}$ thick and are present in the approximate southwestern 60 percent of the parish. The upland terrace aquifer and Chicot aquifer system yield freshwater that is generally soft (hardness less than $60 \mathrm{mg} / \mathrm{L}$ as $\mathrm{CaCO}_{3}$ ) and does not exceed the EPA's SMCLs for chloride, iron, manganese, and dissolved solids. Reported well yields range from about 5 to $950 \mathrm{gal} /$ min. Withdrawals in 2005 were about $9 \mathrm{Mgal} / \mathrm{d}$ from the upland terrace aquifer and about $1 \mathrm{Mgal} / \mathrm{d}$ from the Chicot aquifer system. About $6 \mathrm{Mgal} / \mathrm{d}$ were withdrawn at the Kisatchie well field in 2005. Water levels in the aquifer and aquifer system are close to predevelopment levels in western Rapides Parish; however, near the Kisatchie well field, water levels have declined locally by 10 to $20 \mathrm{ft}$ since withdrawals from the well field began in about 1968 .

\section{Evangeline Aquifer}

The Evangeline aquifer is present in the southern one-third of Rapides Parish and probably merges with the overlying Red River alluvial aquifer, upland terrace aquifer, and Chicot aquifer system. The base of the aquifer dips to the south and ranges from about $0 \mathrm{ft}$ NGVD 29 near Woodworth to about 1,000 ft below NGVD 29 south of Glenmora. The aquifer generally consists of about 50 feet of fine to medium sand and some locally occurring coarse sand. The aquifer yields freshwater that is generally soft and does not exceed the EPA's SMCLs for chloride, iron, manganese, and dissolved solids. About 130 wells are screened in the Evangeline aquifer, and most are used for domestic (60), irrigation (37), public-supply (27), or industrial (4) purposes. Reported well yields range from about 30 to $540 \mathrm{gal} / \mathrm{min}$, and withdrawals from the Evangeline aquifer were about $3 \mathrm{Mgal} / \mathrm{d}$ in 2005. Water levels in the Evangeline aquifer have generally declined by about 5 to $20 \mathrm{ft}$ from 1980 to 2004 and ranged from about 40 to $220 \mathrm{ft}$ above NGVD 29 in 2005.

\section{Williamson Creek and Carnahan Bayou Aquifers}

The Williamson Creek aquifer and underlying Carnahan Bayou aquifer compose the Jasper aquifer system in Rapides Parish. These aquifers are the deepest source of fresh groundwater in the parish, dip to the south, and crop out at ground surface in northern Rapides Parish. Withdrawals from the Jasper aquifer system are primarily from wells in the Kisatchie well field and Alexandria.

The Williamson Creek aquifer is present in the approximate southern 90 percent of Rapides Parish. The aquifer consists of numerous lenses of very fine to medium 
sand and some locally occurring coarse sands that are typically about $50 \mathrm{ft}$ thick. The base of the aquifer ranges from $0 \mathrm{ft}$ NGVD 29 in the northwest to 2,500 ft below NGVD 29 in the south. The aquifer yields freshwater that is generally soft and does not exceed the EPA's SMCLs for chloride, iron, manganese, and dissolved solids (table 3). About 270 wells are screened in the Williamson Creek aquifer, and most are used for domestic (193) or publicsupply (44) purposes. Reported well yields range from about 20 to $550 \mathrm{gal} / \mathrm{min}$. Withdrawals from the Williamson Creek aquifer were about $4 \mathrm{Mgal} / \mathrm{d}$ in 2005. Water levels in the Williamson Creek aquifer have been lowered (fig. 4) by withdrawals in the Alexandria-Pineville area and at the Kisatchie well field. In southeastern Rapides Parish, the aquifer is underlain with saltwater.

The Carnahan Bayou aquifer is present throughout Rapides Parish; however, large areas contain saltwater. The aquifer consists of numerous lenses of very fine to medium sand that are typically about $40 \mathrm{ft}$ thick. The base of the Carnahan Bayou aquifer ranges from $0 \mathrm{ft}$ NGVD 29 in northwestern areas of the parish to 4,000 ft below NGVD
29 in southern areas. In most of Rapides Parish, the aquifer yields fresh water that is soft and does not exceed the EPA's SMCLs for chloride, iron, manganese, and dissolved solids (table 3); however, in areas south of the cities of Sieper, Alexandria, and Kolin, the aquifer contains freshwater underlain with saltwater or only contains saltwater. About 210 wells are screened in the Carnahan Bayou aquifer, and most are used for domestic (122) or public-supply (71) purposes. Reported well yields range from 5 to $710 \mathrm{gal} /$ min. Withdrawals from the Carnahan Bayou aquifer were about $14 \mathrm{Mgal} / \mathrm{d}$ in 2005. Water levels in the Carnahan Bayou aquifer declined from 1968 to 1989 but have been stable since 1989 (fig. 4). The greatest declines (up to 150 $\mathrm{ft}$ ) have occurred in the Alexandria-Pineville area where water levels are deeper than $200 \mathrm{ft}$ below NGVD 29. Saltwater encroachment has degraded water quality at the Kisatchie well field and Alexandria-Pineville areas. Saltwater encroachment will likely continue under 2004 pumping conditions.

Table 3. Summary of selected water-quality characteristics for freshwater in the Williamson Creek and the Carnahan Bayou aquifers in Rapides Parish, Louisiana, 1937-2003 (U.S. Geological Survey, 2008b).

[Values are in milligrams per liter, except as noted ${ }^{\circ} \mathrm{C}$, degrees Celsius; $\mathrm{PCU}$, platinum cobalt units; $\mu \mathrm{S} / \mathrm{cm}$, microsiemens per centimeter; $\mathrm{SU}$, standard units; $\mathrm{CaCO}_{3}$, calcium carbonate; $\mu \mathrm{g} / \mathrm{L}$, micrograms per liter; NA, not applicable; SMCL, Secondary Maximum Contaminant Level established by the U.S. Environmental Protection Agency, 2006]

\begin{tabular}{|c|c|c|c|c|c|c|c|c|c|}
\hline & $\begin{array}{l}\text { Temperature } \\
\qquad\left({ }^{\circ} \mathrm{C}\right)\end{array}$ & $\begin{array}{l}\text { Color } \\
\text { (PCU) }\end{array}$ & $\begin{array}{c}\text { Specific } \\
\text { conductance, } \\
\text { field } \\
\left(\mu \mathrm{S} / \mathrm{cm} \text { at } 25^{\circ} \mathrm{C}\right)\end{array}$ & $\begin{array}{l}\text { pH, } \\
\text { field } \\
\text { (SU) }\end{array}$ & $\begin{array}{l}\text { Hardness } \\
\left(\text { as } \mathrm{CaCO}_{3} \text { ) }\right.\end{array}$ & $\begin{array}{c}\text { Chloride, } \\
\text { filtered } \\
\text { (as CI) }\end{array}$ & $\begin{array}{c}\text { Iron, } \\
\text { filtered } \\
(\mu \mathrm{g} / \mathrm{L} \text { as } \\
\mathrm{Fe})\end{array}$ & $\begin{array}{c}\text { Manganese, } \\
\text { filtered } \\
\text { ( } \mu \mathrm{g} / \mathrm{L} \text { as } \mathrm{Mn} \text { ) }\end{array}$ & $\begin{array}{l}\text { Dissolved } \\
\text { solids, } \\
\text { filtered }\end{array}$ \\
\hline \multicolumn{10}{|c|}{ Williamson Creek aquifer } \\
\hline Median & 22 & 5 & 475.5 & 7.8 & 15 & 17 & 100 & 20 & 304 \\
\hline 10th percentile & 20 & 0 & 248.1 & 6.64 & 8 & 4.1 & 21 & 0 & 167.9 \\
\hline 90th percentile & 25.5 & 11.5 & 799.3 & 8.46 & 58.2 & 77.6 & 594 & 98 & 523.5 \\
\hline Number of samples & 24 & 36 & 44 & 45 & 93 & 93 & 32 & 23 & 40 \\
\hline $\begin{array}{l}\text { Percentage of samples that meet } \\
\text { SMCLs }\end{array}$ & NA & 92 & NA & 84 & NA & 100 & 77 & 72 & 87 \\
\hline \multicolumn{10}{|c|}{ Carnahan Bayou aquifer } \\
\hline Median & 23.5 & 10 & 454.5 & 7.9 & 10 & 15 & 120 & 15 & 319.5 \\
\hline 10th percentile & 20 & 0 & 269 & 7.2 & 1.3 & 6 & 20 & 0 & 203.7 \\
\hline 90th percentile & 28 & 26.5 & 964.5 & 8.3 & 31.4 & 69 & 350 & 60 & 539.6 \\
\hline Number of samples & 76 & 118 & 126 & 145 & 254 & 258 & 77 & 40 & 118 \\
\hline $\begin{array}{l}\text { Percentage of samples that meet } \\
\text { SMCLs }\end{array}$ & NA & 67 & NA & 91 & NA & 100 & 87 & 84 & 87 \\
\hline \multicolumn{10}{|c|}{ SMCLs } \\
\hline & NA & 15 & NA & $6.5-8.5$ & NA & 250 & 300 & 50 & 500 \\
\hline
\end{tabular}



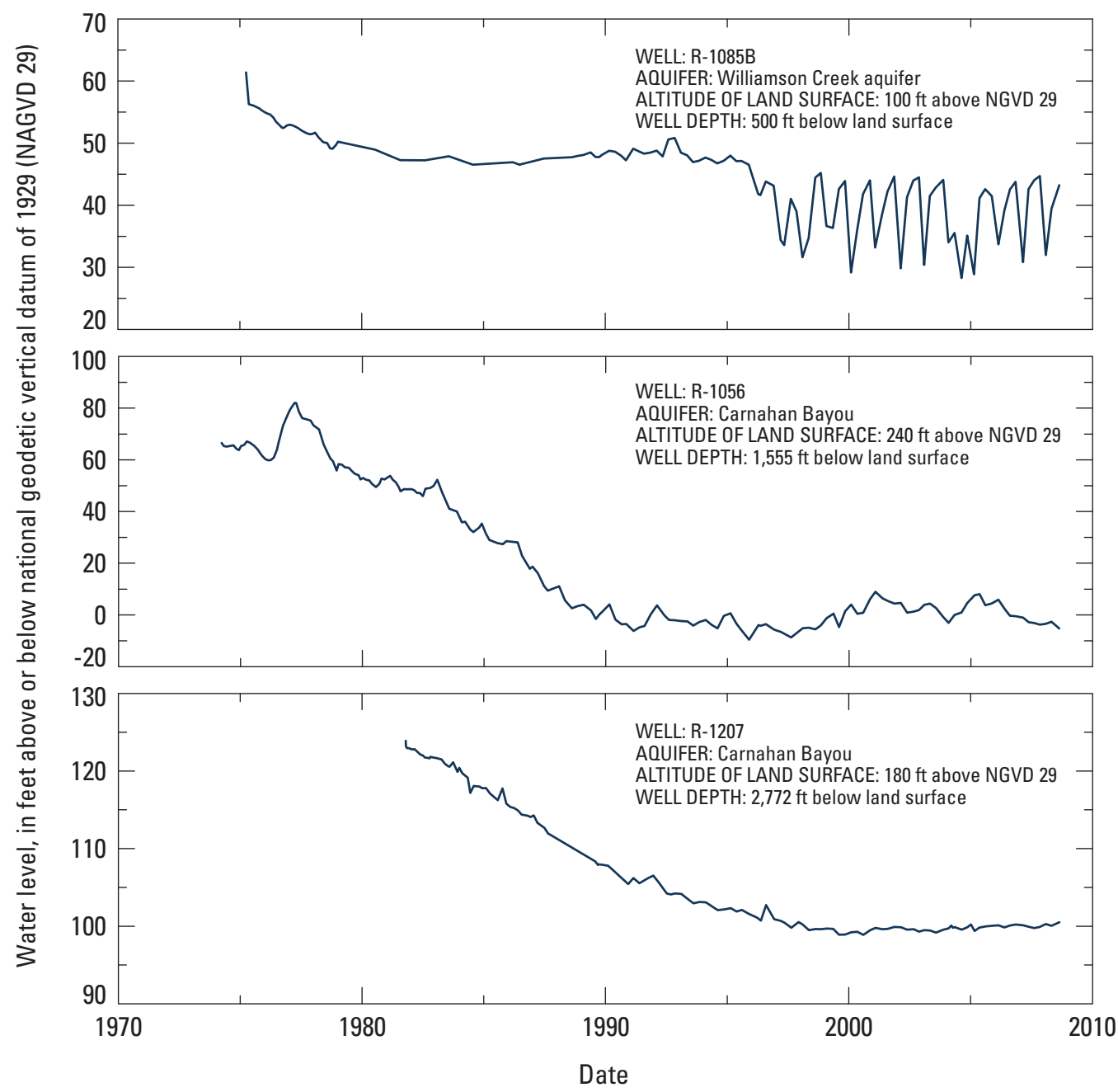

Figure 4. Water levels in well R-1085B screened in the Williamson Creek aquifer and wells R-1056 and R-1207 screened in the Carnahan Bayou aquifer in Rapides Parish, Louisiana (see fig. 1 for well locations).

\section{Surface-Water Resources}

The Red River, Bayou Boeuf, Calcasieu River, Chatlin Lake Canal, and Lake Rodemacher are primary sources of fresh surface water in Rapides Parish. Other sources of fresh surface water in the parish include Bayou Robert, Cotile Lake, and the Indian Creek and Kincaid Reservoirs. In 2005, about $409 \mathrm{Mgal} / \mathrm{d}$ of surface water were withdrawn in Rapides Parish for power generation (402 Mgal/d), rice irrigation (5 Mgal/d), and aquaculture (1 Mgal/d).

The Red River is a potential source of substantial volumes of water in the parish. The average discharge for the Red River at Alexandria was about 30,900 cubic feet per second $\left(\mathrm{ft}^{3} / \mathrm{s}\right)(19,900 \mathrm{Mgal} / \mathrm{d})$ for the period 1929-83. Water in the Red River is hard $\left(121-180 \mathrm{mg} / \mathrm{L}\right.$ as $\mathrm{CaCO}_{3}$ ) to very hard (greater than $181 \mathrm{mg} / \mathrm{L}$ as $\mathrm{CaCO}_{3}$ ) (table 4). Water in the Red River generally does not exceed the EPA's SMCLs for $\mathrm{pH}$ and for chloride, sulfate, and iron concentrations. Dissolved oxygen concentrations generally range from 5.9 to $11 \mathrm{mg} / \mathrm{L}$. Water withdrawals from Bayou Boeuf were about $3 \mathrm{Mgal} / \mathrm{d}$ in 2005 and were for irrigation, livestock, and aquaculture use. The average discharge in Bayou Boeuf before 1966 was about 2,800 $\mathrm{ft}^{3} / \mathrm{s}(1,800 \mathrm{Mgal} / \mathrm{d})$.

The Calcasieu River is also a potential source of water in the parish. The average discharge for the Calcasieu River near Glenmora was about $780 \mathrm{ft}^{3} / \mathrm{s}(500 \mathrm{Mgal} / \mathrm{d})$ for the period 1985-2008. Analyses of water quality samples from the river indicate that the water is somewhat acidic (pH less than 6.5) but otherwise does not exceed the EPA's SMCLs (table 4).

Water withdrawals from the Chatlin Lake Canal for irrigation, livestock, and aquaculture use were about $2 \mathrm{Mgal} / \mathrm{d}$ in 2005. The average discharge for Chatlin Lake Canal near Lecompte was about $232 \mathrm{ft}^{3} / \mathrm{s}(150 \mathrm{Mgal} / \mathrm{d})$ for the period 1922-2008. No water quality data are available for Chatlin Lake Canal.

Lake Rodemacher is in northwestern Rapides Parish about 2 miles west of Boyce. It is owned and used by Cleco, Louisiana Energy and Power Authority, and Lafayette Utilities System as a source of cooling water for two power-generating units. Water withdrawals for power generation were about $402 \mathrm{Mgal} / \mathrm{d}$ in 2005. The lake has a surface area of about 3,320 acres and a maximum storage capacity of about 14,100 acre-feet. No water quality data are available for Lake Rodemacher. 
Table 4. Summary of selected water-quality characteristics for the Red and Calcasieu Rivers in Rapides Parish, Louisiana, 1944-2008 (U.S. Geological Survey, 2008b).

[Values are in milligrams per liter, except as noted. ${ }^{\circ} \mathrm{C}$, degrees Celsius; $\mu \mathrm{S} / \mathrm{cm}$, microsiemens per centimeter; $\mathrm{SU}$, standard units; $\mu \mathrm{g} / \mathrm{L}$, micrograms per liter; $\mathrm{CaCO}$, calcium carbonate; NA, not applicable; SMCL, Secondary Maximum Contaminant Level established by the U.S. Environmental Protection Agency, 2006]

\begin{tabular}{|c|c|c|c|c|c|c|c|c|c|c|}
\hline & $\begin{array}{c}\text { Specific } \\
\text { conductance, } \\
\text { field } \\
\left(\mu \mathrm{S} / \mathrm{cm} \text { at } 25^{\circ} \mathrm{C}\right)\end{array}$ & $\begin{array}{l}\text { Oxygen, } \\
\text { dissolved }\end{array}$ & $\begin{array}{l}\text { pH, } \\
\text { field } \\
\text { (SU) }\end{array}$ & $\begin{array}{c}\text { Hardness } \\
\text { (as } \\
\mathrm{CaCO}_{3} \text { ) }\end{array}$ & $\begin{array}{l}\text { Calcium, } \\
\text { filtered } \\
\text { (as Ca) }\end{array}$ & $\begin{array}{c}\text { Magnesium, } \\
\text { filtered } \\
\text { (as } \mathbf{M g} \text { ) }\end{array}$ & $\begin{array}{l}\text { Sodium, } \\
\text { filtered } \\
\text { (as Na) }\end{array}$ & $\begin{array}{c}\text { Chloride, } \\
\text { filtered } \\
\text { (as CI) }\end{array}$ & $\begin{array}{l}\text { Sulfate, } \\
\text { filtered } \\
\text { (as } \mathrm{SO}_{4} \text { ) }\end{array}$ & $\begin{array}{c}\text { Iron, } \\
\text { filtered } \\
(\mu \mathrm{g} / \mathrm{L} \\
\text { as } \mathrm{Fe})\end{array}$ \\
\hline \multicolumn{11}{|c|}{ Red River at Alexandria ${ }^{1}$} \\
\hline Median & 506 & 8 & 7.6 & 130 & 36 & 9.1 & 42 & 72.3 & 49.5 & 42 \\
\hline 10th percentile & 243 & 5.9 & 7.1 & 70 & 20 & 4.2 & 15 & 25.5 & 19 & 7 \\
\hline 90th percentile & 1,210 & 11 & 8.1 & 280 & 78 & 24 & 110 & 215 & 147 & 134 \\
\hline Number of samples & 729 & 362 & 779 & 719 & 551 & 552 & 381 & 777 & 772 & 127 \\
\hline $\begin{array}{l}\text { Percentage of samples that } \\
\text { meet SMCLs }\end{array}$ & NA & NA & 99 & NA & NA & NA & NA & 94 & 100 & 98 \\
\hline \multicolumn{11}{|c|}{ Calcasieu River near Glenmora² } \\
\hline Median & 46 & 8 & 6.4 & 13.5 & 3.5 & 1 & 4.5 & 5.8 & 2.6 & 210 \\
\hline 10th percentile & 30 & 6.7 & 6 & 7.9 & 2 & .4 & 2 & 2.6 & 1.2 & 142 \\
\hline 90th percentile & 67 & 9.5 & 7 & 17 & 5 & 1.2 & 7 & 7.7 & 4 & 230 \\
\hline Number of samples & 21 & 10 & 37 & 20 & 20 & 20 & 18 & 37 & 37 & 5 \\
\hline $\begin{array}{l}\text { Percentage of samples that } \\
\text { meet SMCLs }\end{array}$ & NA & NA & 48 & NA & NA & NA & NA & 100 & 100 & 100 \\
\hline \multicolumn{11}{|c|}{ SMCLs } \\
\hline & NA & NA & $6.5-8.5$ & NA & NA & NA & NA & 250 & 250 & 300 \\
\hline
\end{tabular}

\section{References}

Newcome, Roy, Jr., and Sloss, Raymond, 1966, Water resources of Rapides Parish, Louisiana: Department of Conservation, Louisiana Geological Survey, and Louisiana Department of Public Works Water Resources Bulletin no. 8, 104 p.

Sargent, B.P., 2007, Water use in Louisiana, 2005: Louisiana Department of Transportation and Development Water Resources Special Report no. 16, 133 p.

Smoot, C.W., and Fendick, R.B., Jr., 1998, Hydrogeology and water resources of the Alexandria area, Rapides Parish, Louisiana: Louisiana Department of Transportation and Development Water Resources Technical Report no. 63, 36 p., 1 pl.

Tomaszewski, D.J., 2007, Ground-water resources in Rapides Parish, Louisiana, 2005: Louisiana Department of Transportation and Development Water Resources Technical Report no. 75.

U.S. Environmental Protection Agency, 1992, Secondary drinking water regulations - guidance for nuisance chemicals: U.S. Environmental Protection Agency publication EPA 810/K92-001, 4 p., accessed July 29, 2009, at http://www.epa.gov/ safewater/consumer/2ndstandards.html.

U.S. Environmental Protection Agency, 2006, 2006 Edition of the drinking water standards and health advisories: Washington D.C., U.S. Environmental Protection Agency, Office of Water, $12 \mathrm{p}$.

U.S. Geological Survey, 2008a, Ground-water levels for Louisiana: U.S. Geological Survey digital dataset, accessed May 22, 2008, at http://nwis.waterdata.usgs.gov/la/nwis/gwlevels.
U.S. Geological Survey, 2008b, Water-quality samples for Louisiana: U.S. Geological Survey digital dataset, accessed May 22, 2008, at http://nwis.waterdata.usgs.gov/la/nwis/qwdata.

U.S. Geological Survey, 2008c, StreamStats: U.S. Geological Survey digital dataset, accessed July 28, 2008, at http://streamstats.usgs.gov/gages/viewer.htm.

\section{By Jason M. Griffith}

\section{For additional information, contact:}

Director, USGS Louisiana Water Science Center

3535 S. Sherwood Forest Blvd., Suite 120

Baton Rouge, LA 70816

E-mail: dc_la@usgs.gov

Fax: (225) 298-5490

Telephone: (225) 298-5481

Home Page: http://la.water.usgs.gov

This fact sheet was published by the U.S. Geological Survey, in cooperation with the Louisiana Department of Transportation and Development (DOTD). Thanks are given to Zahir "Bo" Bolourchi, Director, Water Resources Programs, Louisiana Department of Transportation and Development, who contributed to the content and design of the fact sheet. 